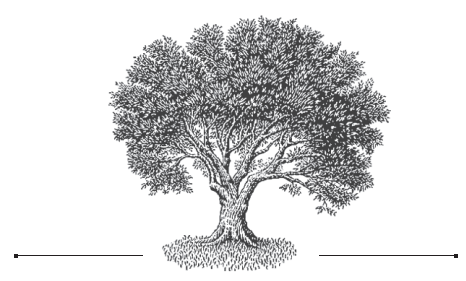

Old Russian

Graffito Inscription in the Abbey

of Saint-Gilles,

South of France

\section{Anne-Sophie Brun}

University of Provence / National Centre for Scientific Research (Aix-en-Provence)

\section{Andreas Hartmann-Virnich}

University of Provence / National Centre for Scientific Research (Aix-en-Provence)

\section{Estelle Ingrand-Varenne}

University of Poitiers, Center for Advanced Studies in Medieval Civilization / National Centre for Scientific Research (Poitiers)

\section{Savva M. Mikheev}

Institute for Slavic Studies of the Russian Academy of Sciences (Moscow)
Древнерусская надпись-граффито

в аббатстве Сен-Жиль на юге Франции
Анн-Софи Брюн
Университет Прованса /
Национальный центр научных
исследований (Экс-ан-Прованс)

Андреас Хартманн-Фирних Университет Прованса /

Национальный центр научных исследований (Экс-ан-Прованс)

Эстелдь Ингран-Варенн

Университет Пуатье, Центр изучения средневековой цивилизации /

Национальный центр научных исследований (Пуатье)

Савва Михайлович Михеев

Институт славяноведения Российской академии наук (Москва)

\title{
Abstract
}

The abbey of Saint-Gilles-du-Gard near Arles in the south of France was one of the most prominent pilgrimage sites in medieval Europe.

Recent archaeological investigation has shown that construction of the abbey church, one of the most significant Romanesque pilgrimage churches in southern France, began ca. 1170/1180. The lower church (crypt) with the tomb of St. Giles (Lat. 
Aegidius, Fr. Gilles) and some of the walls of the upper church belong to that period.

A well-preserved Cyrillic graffito was discovered on a pier of the upper church, close to the spot where the tomb of St. Giles is located in the crypt below. The text contains a prayer with a common formula: ГН ПОМZZH | РАБОУ CВZ|EMOY CDMKZ|BH NHNOCAA|BHYץ 'Lord, help your servant Semko, son of Ninoslav.' Palaeographic and linguistic analysis shows that the graffito is of Russian origin. It was probably made at some time between 1180 and 1250 by a pilgrim travelling from Russia to Santiago de Compostela, and it is the most geographically remote Old Russian graffito inscription discovered so far in western Europe.

Keywords

France, Saint-Gilles-du-Gard, medieval epigraphy, graffiti, palaeography, Cyrillic, Old Russian, pilgrims, pilgrimage roads, Santiago de Compostela, archaeology, building archaeology, 12th century, 13th century

\section{Резюме}

Одним из значительных паломнических центров средневековой Европы было аббатство Сен-Жиль-дю-Гар недалеко от Арля на Юге Франции. Согласно недавним археологическим исследованиям, возведение собора аббатства, одной из наиболее крупных позднероманских паломнических церквей на Юге Франции, началось около 1170/1180 года. К первой стадии строительства относятся нижний храм (крипта) с гробницей святого Эгидия (лат. Aegidius, фp. Gilles) и часть стен верхней церкви.

Хорошо сохранившееся кириллическое граффито было обнаружено на колонне верхней церкви, расположенной рядом с тем местом, под которым в крипте находится гробница св. Эгидия. Текст состоит из модитвы, записанной при помощи типичной формулы: ГН ПОМ ZZ | РАБОУ CBZ|€M OY CDMКZ|ВН NHNOC $\lambda$ A $\mid$ ВНЧю ‘Господи, помоги рабу своему Семку Нинославичу'. По палеографическим и лингвистическим данным граффито является древнерусским и датируется временем не позже конца XIII века, предпочтительно - не позже середины XIII века.

Вероятно, найденное граффито было оставлено паломником, следовавшим из Руси в Сантьяго-де-Компостела примерно между 1180 и 1250 годами. На сегодняшний день это самая западная из выявленных древнерусских надписей-граффити.

\section{Ключевые слова}

Франция, Сен-Жиль-дю-Гар, средневековая эпиграфика, граффити, палеография, кирилдица, древнерусский язык, паломники, паломнические дороги, Сантьягоде-Компостела, археология, архитектурная археология, XII век, XIII век

\section{The Abbey of Saint-Gilles-du-Gard}

Since the early 11th century the abbey of Saint-Gilles-du-Gard in southern France was one of the most prominent pilgrimage sites in Western Europe. Such was the fame of its patron saint, the hermit Giles (Lat. Aegidius), that 12th-century sources refer to the southernmost pilgrimage road to Santiago de Compostela starting in 
Arles as the via Egidiana. A record of the miracles of Saint Giles compiled between 1120 and 1170 and titled Liber miraculorum sancti Egidii suggests that Giles was particularly popular in Germany and in the countries of Northern and Eastern Europe.

The decline of the pilgrimage route and subsequent impoverishment of the monastery led to its secularization in 1538, and religious wars of the late 16th and early 17th century resulted in the destruction of the abbey church. After 1562 the church was used as a Protestant fortress. Its destruction was ordered and partially achieved at the Protestant garrison's departure in 1622. The spire was undermined to make it collapse, and the collapse caused severe damage to the transept and choir. In 1650-1655 a new church, fitted with a new polygonal apse, was erected within the six westernmost bays of the Romanesque nave. The dismantled choir and transept served as a quarry, and leftover stone was sold for a profit. The new church was rib-vaulted at a lower height than the medieval church, and the rib-vaulting was done in a post-gothic style popular in the southern regions of 17th-century France [HARTMANN-VIRNICH 2013B].

Beginning in 2009, a French-German archaeological research program conducted by the Laboratoire d'Archéologie Médiévale et Moderne en Méditerranée in Aix-en-Provence (LA3M UMR 7298 University of Aix-Marseille / CNRS) and the Institute of History of Architecture of the University of Stuttgart, has performed a stone-by-stone survey and analysis of the church and the ruins of monastic buildings of the abbey of Saint-Gilles-du-Gard. The team was directed by A. Hartmann-Virnich, Klaus Jan Philipp, and Heike Hansen. ${ }^{1}$ Archaeological excavations were performed on the site where the cloister garth used to be. ${ }^{2}$ Building archaeology, numismatic and carbon dating have now firmly established that the construction of the existing church did not start in 1116, as one of its inscriptions seemed to suggest. The stone with the inscription, presently located in the southern wall of the Romanesque crypt, was reused in the last quarter of the 12th century together with other ashlar material from the earlier building. In keeping with the dimensions of the largest pilgrimage churches of the time, the 12th-century church was built on a much larger scale than the earlier structure.

Though the late Romanesque abbey church was never completed, it was used for worship, as soon as the crypt and lower parts of the nave were ready. Pilgrims

1 Program ANR-DFG AEGIDIANA-AEGIDIANA-L'abbaye de Saint-Gilles-duGard. Recherches archéologiques, d'archéologie du bâti et archivistiques sur l'histoire monumentale d'un chef d'ouvre oublié de l'art roman en France / Die Abtei Saint-Gillesdu-Gard. Bauforschung, Archäologie und archivalische Studien zur Baugeschichte eines vergessenen Hauptwerks der französischen Romanik. Co-directors: A. Hartmann-Virnich, Laboratoire d'Archéologie Médiévale et Moderne en Méditerranée LA3M UMR 7298 Aix-Marseille Université AMU / CNRS; K. J. Philipp and H. Hansen, Institut für Architekturgeschichte IFAG, University of Stuttgart.

2 Cf. the works [HARTMANN-VIRNich 2011; Buffat, SCHNEIDER, HARTMANN-VIRNICH 2011; HaRTMANN-VIRNICH 2012; 2013A; HaRTMANN-VIRNICH, HANSEN 2011; 2013A; 2013B; 2014; ECHTENACHER, HARTMANN-VIRNICH, HANSEN 2012; HARTMANNVIRNICH Et Al. 2013]. 
had access to the three westernmost bays and to a large staircase in the third bay of the main nave. The staircase led into the lower church with its tomb of saint Giles in the fourth bay of the central nave. In the upper church, the bays of the central nave beyond those accessible to the pilgrims were concealed behind a choir screen. It was shaped like a large transverse wall and built at a later date between the western piers of the bay. Although at present there are no traces of solid walls between the central nave and the aisles, there can be no doubt that those spaces used to be separated, possibly by wooden screens or stalls of the choir. An altar was located in the fourth bay, one level above the tomb of the saint in the crypt. Another staircase, used exclusively by the monks, allowed access to the choir from the cloisters. The door from the crypt to that staircase was located in the third bay of the south aisle. The last of the three staircases, constructed at an earlier stage, provided access from the upper altar to the tomb of saint Giles below. It was built into the northern wall of the central bay of the crypt and adapted to the structure of the upper church.

Archaeological analysis of the church suggests that the construction of the nave was interrupted in the early 13th century. By then the lower church, the four westernmost bays of the aisles of the upper church, and the ambulatory of the upper church had been completed. From ca. 1261 on, construction continued at a slow pace in the eastern bays of the nave and the transept. While later visitors' descriptions suggest that the church was never completed, collapse of the upper stories, absence of iconographic evidence, and contradictions in historical records make it impossible to form a clear picture of the edifice before its ruin. Some parts of the choir were still in existence in the early 19th century, but little survives today.

\section{The Inscription}

A detailed survey of the piers of the upper church by A. Hartmann-Virnich led to the discovery of an as yet unnoticed inscription, scratched on the shaft of the southern column of the south-western pier of the fourth bay from west to east. The pier is close to the altar above the tomb of saint Giles. The enigmatic characters of the inscription are filled with traces of what appears to be 17th-century paint, which suggests that the inscription is older than the 1650-1655 restoration of the church. Although some characters were tentatively identified by the archaeologist as Cyrillic, the hypothesis of a Slavic origin of the inscription seemed altogether implausible. Nevertheless, it was confirmed by further investigation.

The discovery of this highly unusual inscription provided an excellent occasion for a collective study by medievalists from different fields of specialization. Valuable input was provided by A.-S. Brun, masters student in building archaeology and epigraphy in charge of the project of scientific study of the abbey church inscriptions [BRUN 2013; 2014: 273-274, 312-313, fig. 38-41] under overall guidance from A. Hartmann-Virnich who also provided historical and architectural contextualization for the discovery. Further epigraphic 
research by A.-S. Brun and E. Ingrand-Varenne of the Centre d'Études Supérieures de Civilisation Médiévale (CESCM) of the University of Poitiers, with support from S. M. Mikheev, a Slavist who examined the text and its Old Russian context, confirmed the hypothesis of the Slavic origin of the inscription. ${ }^{3}$ The inscription is preserved in situ on the southern side of the south-western pier of the fourth bay of the upper church, erected between ca. 1170/1180 and ca. 1210 (see fig. 1 and 2). The pier rests on a massive square footing which raises its base to ca. $60 \mathrm{~cm}$ above floor level. The base is shared by the pier and its engaged columns. The inscription is engraved above the base on the shaft of the southern column, $1.07 \mathrm{~m}$ above floor level. The area of the inscription is $18.5 \mathrm{~cm}$ wide and $14.5 \mathrm{~cm}$ high. The inscription is well preserved, mostly due to a whitewash coating.

Figure 1. Ground plan of the lower and upper church showing the location of the inscription by the black arrow (H. Hansen, University of Stuttgart, 2009-2012) ${ }^{4}$

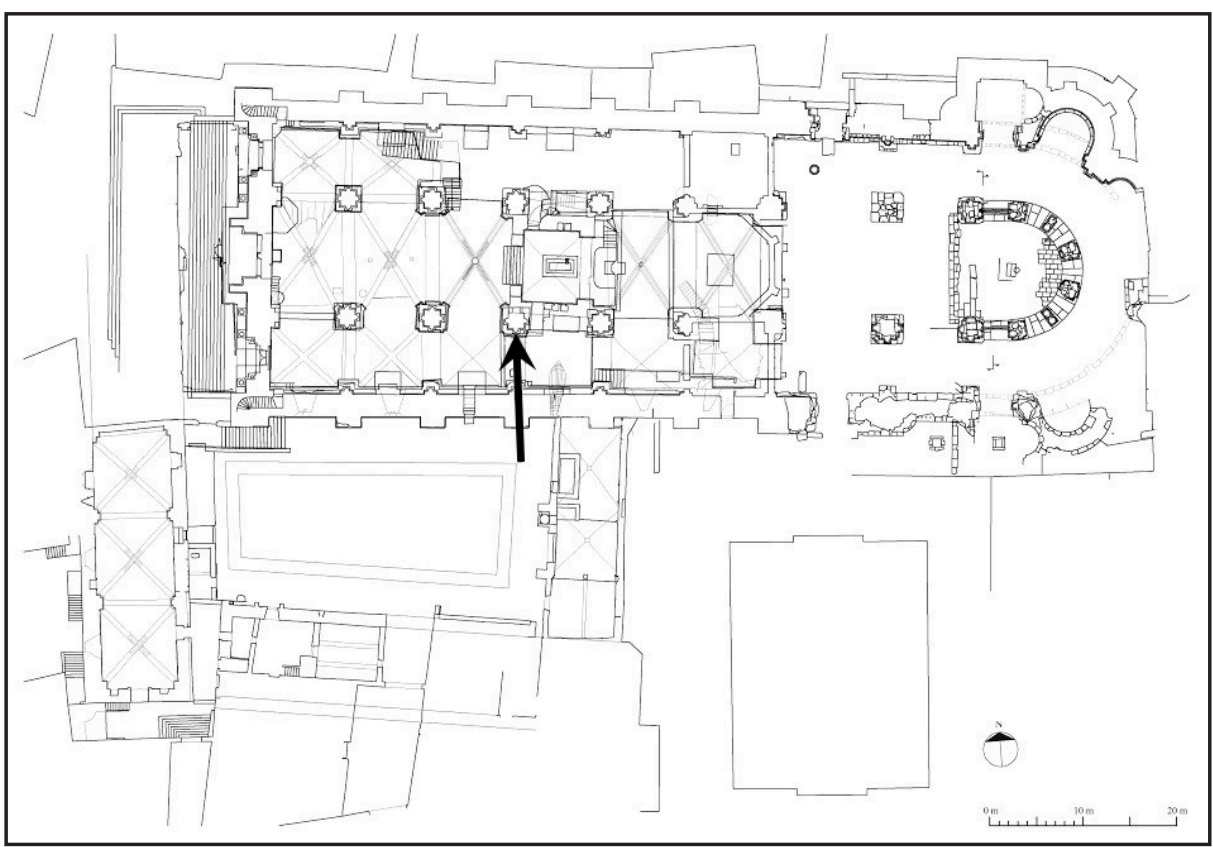

3 We would like to thank Andrey Yu. Vinogradov and Alexander G. Avdeev for their help in connecting the future co-authors of this paper, and Alexey A. Gippius, Aleksandr E. Musin, Ilya B. Itkin, Aleksandr V. Nazarenko, Jos Schaeken for their helpful advice.

4 The to-scale stone-by-stone tacheometrical drawings were created by H. Hansen (Institut für Architekturgeschichte, Universität Stuttgart) for the French-German ANR-DFG research project AEGIDIANA (Laboratoire d'Archéologie Médiévale et Moderne en Méditerranée LA3M UMR 7298 Aix-Marseille Université/CNRS, Institut für Architekturgeschichte, Universität Stuttgart, 2009-2011). 
Notably, the pier is one of the four closest to the tomb of the saint in the lower church, and the inscription is located in the aisle. As stated above, the same pier was adapted at a later date, probably as early as the 13th century, to accommodate a massive choir screen. The screen separated the three western bays accessible to the pilgrims, and the central part of the nave used exclusively by the monastic community. The central part included the altar above the tomb of the saint. The aisles were probably accessible to laymen, visitors and pilgrims alike, and, obviously, the author of the inscription wanted to place it as close to the altar as possible.

Figure 2. Photograph of the pier showing the location of the inscription by the red arrow (A. Hartmann-Virnich)

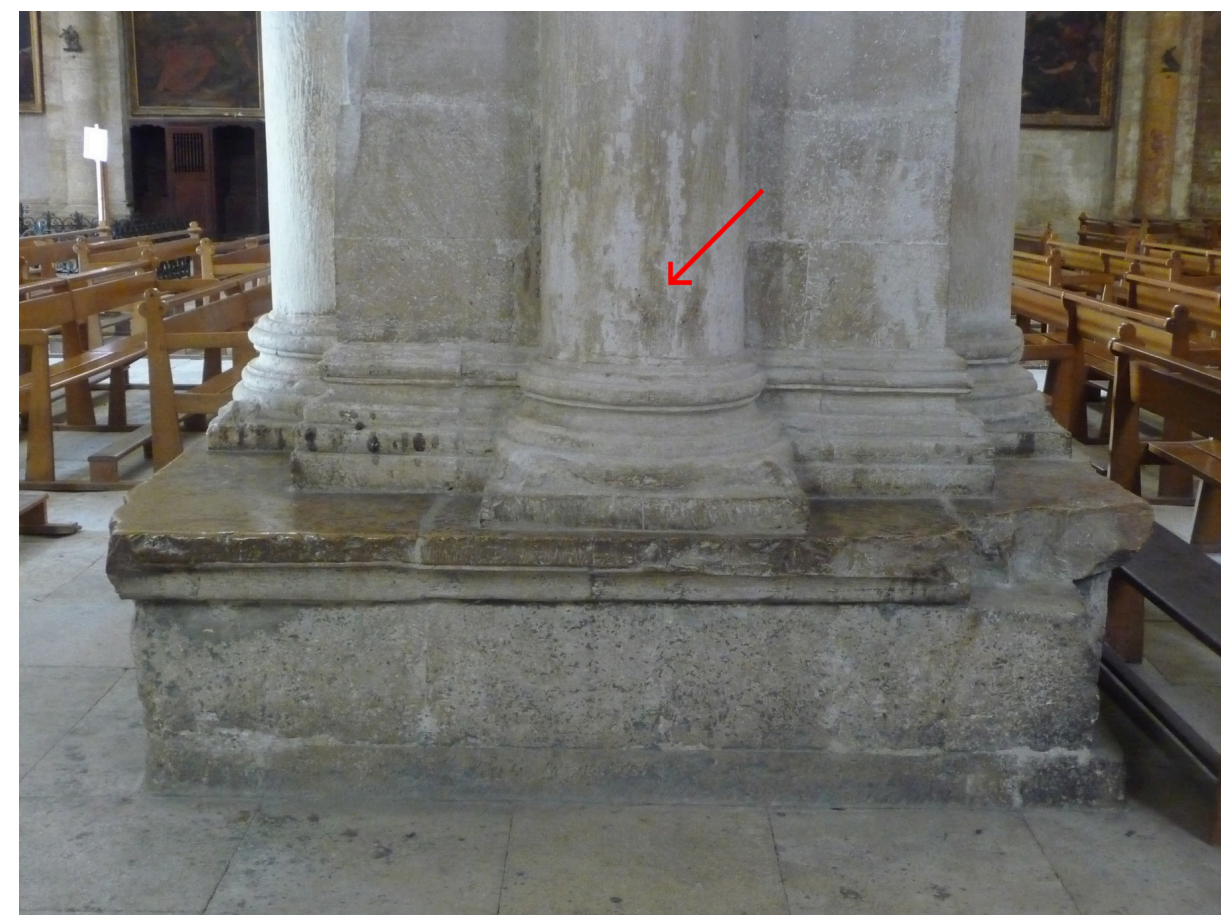

The text of the inscription is laid out in five horizontal lines. The letters were scraped in the stone, not incised by a professional stonecutter's tool. Although the depth of the profile is low, the entire text is legible under strong light beamed from various angles. However, due to deep vertical tool marks on the surface of the stone, some letters are blurred. The two drawings of the inscription shown below (fig. 3) give two slightly different readings of the text. The first drawing was done by direct tracing of the outlines of the letters, and the second-by figuring out the general pattern from photographs. 
Figure 3. Photograph and drawings of the inscription. The photograph was taken by A.-S. Brun, traced from the original by A.-S. Brun (left) and drawn from photographs by S. M. Mikheev (right)
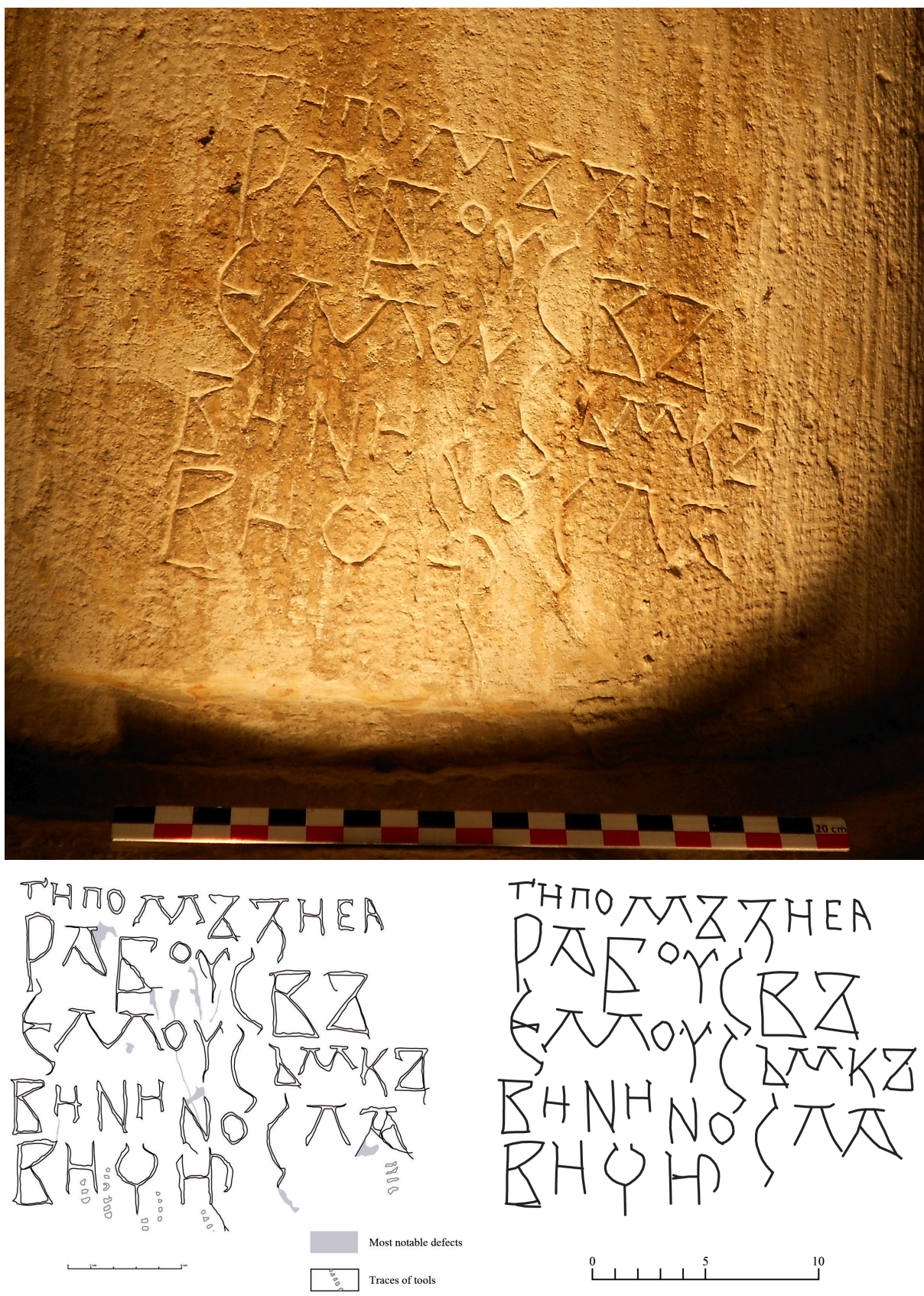
The tracing was done on transparent film and is full scale. The second drawing is a digitally remastered copy of the tracing, proposing a reconstruction of the originally inscribed text. Features deemed accidental and irrelevant to the reading are omitted from the second drawing.

Tool marks around the inscription predate the epigraphic text. Letters were scratched into the surface of the stone. Irregular shape and size of individual letters could result from the fact that the writer did not have a proper cutting tool. Letters vary in size, and their contours are rounded and imprecise. Obviously, the cutter was not a professional, and was not equipped with a chisel and mallet. Although of a harder variety than in other parts of the church, the limestone of the pier was soft enough for fast work with rudimentary tools. It is clear that the inscription was made rather hastily with neither frame, nor pattern.

Letters do not follow a straight line, and lines sometimes curve to avoid crisscrossing letters from the row above. The text is regularly aligned only on the left side. Capital letters are irregular in shape with many size variations. Letters of the first line are particularly small, the first being $0.7 \mathrm{~cm}$ high and $1.7 \mathrm{~cm}$ wide. By comparison, the largest letter of the inscription (the last letter of the second line) is $4.2 \mathrm{~cm}$ high and $2 \mathrm{~cm}$ wide.

Although these features support the classification of the inscription as a graffito, its content is more in line with an inscription proper, a fact which puts in question the traditional division between the two epigraphic genres. In France medieval graffiti have so far been excluded from thorough scientific study, ${ }^{5}$ and are regrettably absent from Robert Favreau's overview of French medieval epigraphy [FAVREAU 1997]. ${ }^{6}$ In Italy the study of graffiti, described by Armando Petrucci as "spontaneous textuality" [Petrucci 1996: 64], ${ }^{7}$ is more advanced [Miglio, TeDESCHI 2012]. A graffito is currently defined as an informal inscription made by a non-professional with any tool at hand. In most cases the author and the inscriber are the same person. A period-specific version of cursive writing is frequently used. Graffiti are further characterized by hasty execution (although a professional stonecutter would have done the same job even faster), and poor legibility. Finally, in many cases graffiti are only detectable under grazing light, and thus easily escape researchers' observation.

Medieval West-European graffiti can be very roughly divided into two periods. From the 6th or 7th century AD to the end of the 12th century, graffiti tend to be found exclusively within religious and sacred context. Devotional graffiti near a sanctuary, near a relic, liturgical or obituary graffiti immortalizing the deceased were the most common types. From the 13th century on,

\footnotetext{
5 [TREFFORT 2004] is one of the exceptions.

6 For a definition, it is necessary to refer to the former article of [LECLERCQ 1925].

7 On graffiti, see also: [KRAacK, Lingens 2001].
} 
graffiti multiply and their content diversifies considerably. They can be found in different places, on different surfaces, and in a multitude of graphic forms [Miglio, Tedeschi 2012].

The inscription in the abbey church of Saint-Gilles seems to belong to the earlier period. It is a traveller's, and more precisely, a pilgrim's graffito, though the formula hic fuit, consistent with graffiti from the late Middle Ages is absent. In the sanctuaries of Christendom the custom of leaving devotional graffiti on walls and columns close to saints' relics, crypts, altars, confessionals, etc. existed among worshipers since an early date. In general terms, a graffito commemorates an individual's visit to the holy place and sometimes gives its date.

Graffiti occupy a somewhat different place among the epigraphic production of Old Russia. Literacy levels were fairly high, and every church that has kept its original interior plastering has hundreds of graffiti left by parishioners. Such well-preserved churches can be found in Kiev, Novgorod, and Polotsk. Most of the inscriptions contain short prayers, or simply name the person praying (the prayer remains implied), yet other content is occasionally represented. ${ }^{8}$ There is a substantial body of Old Russian inscriptions outside Russia: pilgrims' graffiti have been found in Asia Minor, in Bethlehem, in Italy. ${ }^{9}$ They are particularly numerous in Istanbul: out of the seventy Cyrillic inscriptions found there all but one are Russian. ${ }^{10}$

A fair number of the once countless graffiti in and around the abbey church of Saint-Gilles have survived. Two early graffiti are located on the wall of the former arcade of the Romanesque cloisters facing the large western wall of the lower church. Poorly preserved, they are barely visible today, and though individual letters can be distinguished, the whole text remains illegible. Judging by the style, these inscriptions date back to the 12th century, and most likely predate the destruction of the northern walkway of the cloister in the last third of the 12th century when the abbey church was erected. The inscriptions may have referred to tombs originally located in the destroyed walkway [BRUN 2014: 310-311, fig. 35-37]. ${ }^{11}$ Figurative graffiti of an obviously later date are found on column shafts of the façade of the abbey church: men in armour carrying weapons; buildings; a crowned man carrying a fleur-de-lis. Since the 19th century the latter has been identified as St. Louis [RÉvoIL 1873: 64-65, fig. 1-2], although there is no positive proof for this interpretation.

8 On graffiti inscriptions in Old Russia see especially [Медынцева 2000: 74-83; FRANKLIN 2002: 71-74; ФРАНКЛИН 2010: 131-137]. Cf. the newest publications [КОРНІєНКО 1-3; КАЛЕЧЫЦ 2011; ГИППИУС, МИХеЕв 2013].

9 See [Dell’Agata 1973-1974; ДЕл’АГАТА 1978; АРтАмонов, ГИППиус, ЗАЙЦЕв 2014].

10 See [АРтАмонов, ГиППиус 2012; АРтАмонов, ГиПпиус, ЗАЙЦЕв 2012].

11 These two graffiti are not mentioned in the Corpus of inscriptions of medieval France [CIFM 13]. The only published bibliographical reference is [HARTMANN-VIRNICH, HANSEN 2013B: 300]. 
The newly discovered inscription from Saint-Gilles represents a unique case of text written in Cyrillic, previously not found in medieval epigraphic production in France. The majority of French medieval inscriptions are in Latin with a slow shift to vernacular languages in the Late Middle Ages. There are some examples of Greek, Arabic, and Hebrew texts catalogued in the "Corpus des inscriptions de la France médiévale," but no inscriptions in Slavic languages. The very recent discovery of the yet unpublished Saint-Gilles inscription explains its absence in the thirteenth volume of the "Corpus" published in 1988 and dedicated to the epigraphic documents in the Gard, Lozère and Vaucluse departments known at the time [CIFM 13: 65-83 (notices 56-75)]. Two primary reasons explain why this inscription remained undiscovered for so long: first, the engraved text has been partially covered by distemper. Second, the inscription is located in a part of the church with low light, and is therefore not easily visible. Finally, its general appearance of a graffito rather than a formal inscription seems to be responsible for the lack of interest from scholars.

The text reads as follows:

1 ГНПОМZZHЕA

2 РАБОУСВZ

3 EMOYCDMKZ

4 BHNHNOCAA

5 BHYЮ

There are no punctuation marks, no blank spaces between words, and no obvious decorative elements; scriptio continua is used for the whole text. Words are divided between syllables (свъ|емоу, Сьмкъ ви, Ниносла|вичю), which explains the slight variations in the length of the five lines of the inscription. There is only one, very common, abbreviation: the word $\Gamma u(G i)$ is a standard shortening for Гocnoдu (Gospodi) 'Lord,' though the shortening sign on top of the word (титло) is missing (a spelling that is not unknown). This word was rarely written unabbreviated.

There are two Latin letters $E A$ in the end of the first line (after the word nомъзи 'help'), which do not belong to the Old Russian inscription. The first of these symbols is an $\mathrm{E}$ of rectangular shape (unlike the roundish $E$-like letter in the Cyrillic text), the second letter is an A, which is graphically different from a typical Cyrillic A. The two letters are aligned with the other letters of the first line. It seems probable that the Latin letters, which remain unexplained in the context of the Russian text, were added more or less simultaneously by a contemporary who misinterpreted the Cyrillic writing and tried to complete it having in mind a different meaning, which we are unable to reconstruct. 
Normalized transcription and translation of the Old Russian text:

\begin{tabular}{|c|c|c|c|c|c|}
\hline $\mathrm{H}$ & $\begin{array}{l}\text { ПомZZН | } \\
\text { pomozi }\end{array}$ & $\begin{array}{l}\text { РАБОУ } \\
\text { rabu }\end{array}$ & $\begin{array}{l}\text { CBZ|EMOY } \\
\text { svoemu }\end{array}$ & $\begin{array}{l}\text { CDMKZ|BH } \\
\text { semkovi }\end{array}$ & $\begin{array}{l}\mathrm{NH} \\
\text { nir }\end{array}$ \\
\hline & IMPV.2SG & DAT.SG & DAT.SG.M & DAT.SG & DAT. \\
\hline & & & svoi & Sen & Nin \\
\hline & help & servant & POSS.REfl & Semko & son of Ninoslav \\
\hline
\end{tabular}

Translation: 'Lord, help your servant Semko, son of Ninoslav.'

The text is written in the so-called everyday system (бытовая система) which allows to replace letter $e$ with $b$ and letter $o$ with $z-$ noмzзu instead of $<$ помози $>$, свъемоу for $\langle$ своемоу $>$, Сьмкъви for $\langle$ Семкови $\rangle$. Everyday systems of writing of this kind were frequently used in Russia between roughly 1150 and 1300. Inscriptions using the formula Господи помози рабоу своемоу

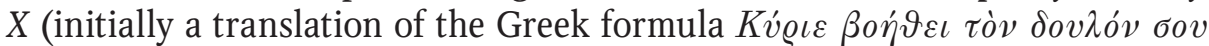
$X)$ are the most common among Old Russian epigraphy (especially in graffiti inscriptions on church walls), competing only with the short formula $X$ nьcaлr 'X wrote (it),' cf. [FRANKLIN 2002: 72; Франклин 2010: 134]. The most noticeable palaeographic features of the inscription are the following: a $p$ with a round loop and straight stroke (type Ia according to [ЗАлизняк 2000]); mirror- $a$ (type 5); $c$ and $e$ with marked serifs. Unfortunately for dating, there is only one position of the tell-tale etymological yer in the inscription. The weak yer (extra-short vowel etymologically) between $\mathcal{M}$ and $\kappa$ is absent in the word Сьмквви <Семкови> which would be normal for an inscription written after 1150 or thereabout. ${ }^{12}$

The name Semko (Семко) is a short form of the Christian name Semeon/ Simeon. Ninoslav (Нинославъ) is a Slavic name, well-known among Southern Slavs [Морошкин 1867: 139]. Its second root -slav- is one of the most common among Slavic personal names, whereas the first root Nin- is less frequent. In Old Russia it can be traced only in Novgorod in forms like Ninoněgz, Ninomirz, Ninzka, Ninzko. ${ }^{13}$ Since the use of non-baptismal names in Russia decreased constantly from the 11th to the 13th century (cf. [ЗАлизняк 2004: 211-216]), it may be concluded that 1180 to 1250 is a more probable dating than the latter half of the 13th century. Dativus singularis with the ending

12 Palaeographic and linguistic dating according to [ЗАлизняк 2000]: 1140-1280, preferred 1160-1280. Dating features: $a$ (type 5) "mirror" (1140-1380, prefer. after 1160); в (type V) "the lower sidelong line-unto the mast" (after 1140, prefer. before 1380); $\partial$, $\pi, \ldots, a$ regularly with cover (3/3) (before 1280); $M$ (type 2) "top serifs" (prefer. before 1280); language: the extra-short vowels are lost (1×) (after 1120, prefer. after 1160).

13 Cf. [ВАсильев 2005: 211-212; 2012: 268]. The name * Ninomirz probably appears in the Saint Sophia Cathedral, Novgorod, inscriptions №№ 18 and 50 which its publisher did not decipher properly [МедынцевА 1978: 42, 65] (the reading was suggested by A. A. Gippius). 
-ovi (instead of $-u$ ) was very common in South-Western, Western and NorthWestern parts of Russia. However, in the Novgorod region it was not in use after the beginning of the 13th century [ЗАлизняк 1986: 134-135; Иткин, КОГАн 2006]. The use of Dativus singularis -ovi (Сьмквви) and the lack of ts-ch merger (Нинославичю) in the Saint Gilles inscription points to the fact that Semko was not from Novgorod.

\section{Russian Pilgrims on the Road to Santiago de Compostela}

The newly-found graffito is the most remote of known Old Russian inscriptions. Fortunately, we can demonstrate that Semko Ninoslavich was not the only Old Russian pilgrim to follow the pilgrimage roads between Rome and Santiago de Compostela.

There are many objects that were brought to Russia by pilgrims from the West-from Rome to Cherven' (nowadays-Czermno in Poland) at the end of the 12th and in the 13th century, from Bari to Novgorod at the end of the 12th century, from Santiago de Compostela to Novgorod, Staraya Russa, Vitebsk (present day Belarus), and Iziaslavl' (nowadays-Shepetivka in Ukraine) in the 13th, 14th, and 15th centuries. ${ }^{14}$

On the road from Rome to Santiago, in St. Martin's Cathedral in Lucca, two Russian pilgrims left their graffiti between the mid-11th and the mid-13th century. According to the study published in [Dell'Agata 1973-1974] and [ДЕл’АгАтА 1978], the first text reads:

\begin{tabular}{|c|c|c|c|}
\hline$\lambda A Z, \mathrm{~PB}$ & ПСАגZ & АР[Ы]|ШЕВНҮЬ & РОСТН[СЛА]|В $\lambda Ь$ \\
\hline Lazorb & psalъ & $\operatorname{Jar}[y]$ ševičb & Rosti[sla]vlı \\
\hline NOM.SG & L-PART.SG.M & NOM.SG.M & NOM.SG.M \\
\hline Lazorb & pbsati & Jaryševičb & Rostislavlь \\
\hline Lazor' & write & son of Yarysh & of Rostislav \\
\hline
\end{tabular}

Translation: 'Lazor' wrote, son of Yarysh, [. . .] of [the prince] Rostislav.'

The inscription is quite decorative, with a ligature $m u$ at the end of the second line. The most probable reconstruction of the patronymic is $A p[b]$ шевичь (Jar $[y] \check{\text { ševič } b) .} .^{15}$ There is an additional slanting line after the dot in the third line, which probably was the first line of a letter left unfinished by Lazor'. This line can be attributed to an $\pi(l)$, a $\partial(d)$ or an $\mathcal{M}(m)$. It can be interpreted as the first letter of a new word, which contextually would have to be a noun. Per-

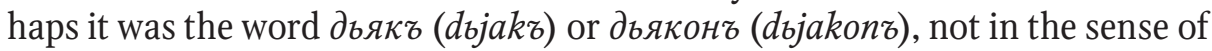

\footnotetext{
${ }^{14}$ Particularly about these finds see [Мусин 2009: 252-256; Musin 2012].

${ }^{15} \mathrm{Cf}$. the name Jary̌s in three birchbark letters of the 12th and 13th centuries from Novgorod and Smolensk [ЗАлизняк 2004: 822], Jaryševa, name of the street in Novgorod (first mentioned in 1195), and Ivan Yaryshevich, a Novgorodian, mentioned in the chronicle in 1217 [НПЛ: 57, 258].
} 
'deacon,' but in the sense of 'scribe,' i.e., 'scribe of Rostislav.' In Old Russia the name Rostislav was used only by the ruling dynasty of Rurikids, and was one of their favourite names in the 12th and 13th centuries. Some help to identify the prince may be provided by the second Russian graffito from Lucca, which is much smaller in size and immediately follows the inscription of Lazar':

\begin{tabular}{|c|c|c|}
\hline $\begin{array}{l}\text { Abьakonz } \\
\text { dbjakonъ }\end{array}$ & $\begin{array}{l}\text { моуро|мьскън } \\
\text { murombskъi }\end{array}$ & $\begin{array}{l}\Pi c a \lambda z \\
\text { psalı }\end{array}$ \\
\hline NOM.SG & NOM.SG.M & L-PART.SG.M \\
\hline $\begin{array}{l}\text { dьjakonъ } \\
\text { scribe }\end{array}$ & $\begin{array}{l}\text { murombskъi } \\
\text { of Murom }\end{array}$ & $\begin{array}{l}\text { pbsati } \\
\text { write }\end{array}$ \\
\hline
\end{tabular}

Translation: 'Scribe from Murom wrote [it].'16 As we have already mentioned above, the word drjakonz was used in Old Russian in two senses'deacon' and 'scribe' and in our case there are some clues for a preferential reading. The quoted graffito stands out with its strange formula. Hundreds of Old Russian inscriptions use the formula $X$ pbsalz 'X wrote [it],' but there is no name of the author in this case. That is why this text probably has to be treated as a complement to the unfinished inscription of Lazar'. In that case the two inscriptions from Lucca would in fact be a single graffito of Lazar' Yaryshevich, a scribe of Rostislav, prince of Murom. The only Rostislav to rule in Murom was Rostislav, Yaroslav's son, who ruled the principality of Murom in 1145-1147 and $1149-1153 .{ }^{17}$

The reason why Russian pilgrims worshipped the tomb of St. Giles may be found in Polish history. It would have been widely known in Old Russia that the birth of the future Polish king Bolesław III Wrymouth (1086-1138), son of Władysław I Herman, had been attributed to the help of saint Giles. Władysław I Herman ordered the construction of no fewer than three churches dedicated to Saint Aegidiusz in Kraków, Inowlodz and Giebultow. By 1102 Bolesław married a Russian princess Zbyslava, daughter of Sviatopolk, prince of Kiev. Two sisters and two daughters of Bolesław were married to Russian princes.

16 This graffito stands out with its dialect East Slavic $-z u(-z i)$ instead of $-b u(-y i)$ in an unstressed position [СоБолЕвский 1907: 229-233].

17 The dual inscription of Lazar' Jaryshevich is reminiscent of a scribe's inscription in the St. Sophia Cathedral in Novgorod which also falls in two parts: a carefully done beginning and a sloppy ending. Graffito no. 115/252 reads: MRTHЖHPZ

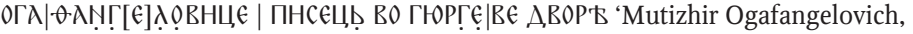
scribe at the Giurgi's (= George's) court' [Гиппиус, Михевв 2013: 161-162] (somewhere in the middle of the second line the shape of the letters and the graphic system change altogether). It seems that at least two Old Russian scribes incising their graffiti on church walls in the 11th-12th centuries used two ways of writing in their texts: Mutizhir, scribe of Giurgi (probably identical to Giuriata, who was a Novgorod posadnik in the end of the 11th-beginning of the 12th century), and Lazar', scribe of prince Rostislav in the middle of the 12 th century. 


\section{Conclusions}

The recently discovered Old Russian Cyrillic graffito in the church of the abbey of Saint-Gilles-du-Gard was made no earlier than 1170 or 1180 and, most likely, no later than 1250 or thereabout. The terminus post quem is based on thorough examination of new building archaeology data for the abbey church, and the terminus ante quem on palaeographic and linguistic analysis of the inscription.

Scratched onto a column in the upper church as close as possible to where there used to be an altar one floor above the tomb of St. Giles, the graffito was probably made by a pilgrim. It is the only direct evidence of the worship of this saint in Russia, and at the same time the most significant evidence of the pilgrimage from Old Russia to Santiago de Compostela.

\section{Bibliography}

\section{BRUN 2013}

Brun A.-S., Archéologie du bâti et Épigraphie médiévale. L'exemple de l'Abbatiale de Saint-Gillesdu-Gard (masters thesis, 1-2, Aix-Marseille Université, 2013). 2014

Brun A.-S., "Les inscriptions lapidaires de l'abbaye saint-gilloise: inventaire et étude, entre problématiques méthodologiques et résultats de la recherché,” in: A. Hartmann-Virnich, H. Hansen, M.-P. Bonetti, A.-S. Brun, Projet collectif de recherche "AEGIMAIOR. L'ancienne abbaye de Saint-Gilles-du-Gard. Archéologie et histoire monumentale d'un site monastique majeur du Midi de la France." Année 2012, $n^{\circ}$ d'autorisation 12/557-8899 (Rapport de complément d’activité. Janvier 2014, Montpellier, 2014, 253-339).

BUFFAT, SCHNEIDER, HARTMANN-VIRNICH 2011 Buffat L., Schneider L., Hartmann-Virnich A., "Saint-Gilles: Les Jardins du Cloître," Bilan scientifique de la région Languedoc-Roussillon 2010, 2011, 85-86.

CIFM 13

Favreau R., Michaud J., Mora B., éd., Corpus des inscriptions de la France médiévale, 13: Gard, Lozère, Vaucluse, Paris, 1988.

Dell'AgATA 1973-1974

Dell'Agata G., "Antiche iscrizioni cirilliche nel Duomo di Lucca," Ricerche slavistiche, 20-21, 1973-1974, 5-14.

ECHTENACHER, HARTMANN-Virnich, HANSEN 2011

Echtenacher G., Hartmann-Virnich A., Hansen H., "Reconstructing the Building Process of Saint-Gilles-du-Gard Abbey. 3-D Modelling as an Instrument for Archaeological Analysis of Historic Architecture. Work in progress,” in: C. Père, J. Rollier-Hanselmann, éd., ArchI-Tech 2010: Actes du colloque. Cluny (France), 17-18-19 novembre 2010 (= Archéovision, 5), Bordeaux, 2011, 171-77.

FAVREAU 1997

Favreau R., Épigraphie médiévale, Turnhout, 1997.

FRANKLIN 2002

Franklin S., Writing, Society, and Culture in Early Rus, c. 950-1300, Cambridge, 2002. 
HARTMANN-VIRNICH 2010

Hartmann-Virnich A., "Saint-Gilles-du-Gard. Projet de recherche AEGIDIANA," Bilan scientifique de la région Languedoc-Roussillon 2009, 2010, 90-92.

2012

HARTMANN-Virnich A., "L'inscription de la fondation de l'abbatiale de Saint-Gilles-du-Gard: réflexions sur un problème archéologique," in: R. Alcoy ET AL., éd., Le plaisir de l'art du Moyen Age. Commande, production et réception de l'uvre d'art. Mélanges en hommage à Xavier Barral $i$ Altet, Paris, 2012, 140-148.

2013A

HARTMANN-VIRnich A., "Saint-Gilles. AEGIMAIOR ancienne abbatiale de Saint-Gilles-duGard," Bilan scientifique de la région Languedoc-Roussillon 2012, 2013, 100-101.

2013B

HARTMANN-Virnich A., "«Et le dessain dicelle nestre pas en forme deglize». Déchéance, infortune et réparation de l'abbatiale de Saint-Gilles-du-Gard aux XVI et XVII e siècles," in: C. Blondeau, B. Boissavit-Camus, Y. Boucherat, P. Volti, éd., Ars auro gemmisque prior: Mélanges en hommage à Jean-Pierre Caillet (= Dissertationes et monographiae), Zagreb, Motovun, 2013, 259-266.

HARTMANN-VIRNICH ET AL. 2013

Hartmann-Virnich A., Brun A.-S., Crespin A., Bonetti M.-P., Dabas M., Guibal F., Jallet-Pons C., Hansen H., Bénézet J., Palazzo-Bertholon B., Vacheyroux G., Projet collectif de recherche "AEGIMAIOR. L'ancienne abbaye de Saint-Gilles-du-Gard. Archéologie et histoire monumentale d'un site monastique majeur du Midi de la France." Rapport pour l'année 2012, Montpellier, 2013.

HARTMANN-VIRNICH, HANSEN 2010

HARTMANn-Virnich A., HANSEn H., "Saint-Gilles, ancienne abbaye, programme de recherche franco-allemand ANR-DFG AEGIDIANA," Bilan scientifique de la région Languedoc-Roussillon 2010, 2010, 82-84.

$2013 \mathrm{~A}$

Hartmann-Virnich A., Hansen H., dir., L'ancienne abbaye de Saint-Gilles-du-Gard: Nouvelles recherches sur un monument majeur de l'art roman (= Bulletin monumental, 171/4), Paris, 2013.

2013в

Hartmann-Virnich A., Hansen H., "Saint-Gilles-du-Gard: L'église abbatiale et les bâtiments monastiques: Nouvelles recherches archéologiques," in: HARTMANN-VIRNICH, HANSEN 2013A, 293-339.

2014

Hartmann-Virnich A., Hansen H., "Saint-Trophime in Arles und Saint-Gilles-du-Gard. Neuere und aktuelle archäologische Forschungen zu den romanischen Kirchenbauten und ihren Skulpturenfassaden an der provençalischen Via Egidiana," in: B. NicolaI, ed., Santiago de Compostela. Pilgerarchitektur und bildliche Repräsentation in neuer Perspektive. Arquitectura de peregrinación y representaciones iconológicas desde una nueva perspectiva. Pilgrimage Architecture and Pictorial Concepts in a New Perspective. Actes du colloque international, Berne, 25-27 mars 2010, Bern, to be published in 2014.

KRAACK, LINGENS 2001

KraACK D., Lingens P., Bibliographie zu historischen Graffiti zwischen Antike und Moderne, Krems, 2001.

LECLERCQ 1925

LeCLERCQ H., "Graffites," in: Dictionnaire d'archéologie chrétienne et de liturgie, 6/2, Paris, 1925, $1501-1541$. 
Miglio, Tedeschi 2012

Miglio L., Tedeschi C., "Per lo studio dei graffiti medievali. Caratteri, categorie, esempi," in: P. Fioretti, ed., Storie di cultura scritta. Scritti per Francesco Magistrale, Spoleto, 2012, 605-628.

MUSIN 2012

Musin A., “Z wiecznego Rzymu nad Bug - znaki pielgrzymie z Czermna (Czerwienia). Aus dem ewigen Rom bis zum Bug: Die Pilgerzeichen aus Czermno (Červen'). Da Roma città eterna al fiume Bug Occidentale: placchette di pellegrini da Czermno (Červen'). От Вечного Рима к течению Буга: паломнические реликвии из Чермно (Червеня)," in: J. BAGIŃsKA, M. Piotrowski, M. WoŁoszyn, red., Czerwień - gród między Wschodem a Zachodem: Katalog wystawy. Červen' - eine Burg zwischen Ost und West: Ausstellungskatalog. Červen' - un castrum tra Oriente e Occidente: Catalogo della mostra. Червень - град між Сходом і Заходом: Каталог виставки, Tomaszów Lubelski, Leipzig, Lublin, Rzeszów, 2012, 243-255.

PETRuCCi 1996

Petrucci A., “Graffito”, in: Enciclopedia dell'arte medievale, 7, Roma, 1996, 64-66.

RÉVOIL 1873

RÉvoIL H., Architecture romane du midi de la France, 2, Paris, 1873.

TREFFORT 2004

TREffort C., "Les «graffitis» sur tables d'autel aux époques pré-romane et romane. Note à propos des inscriptions de l'autel de Gellone," in: X. BArral i Altet, C. Lauranson-Rosaz, ed., Saint-Guilhem-le-Désert. La fondation de l'abbaye de Gellone. L'autel médiéval. Actes de la table ronde d'août 2002, Aniane, 2004, 137-146.

АртАмонов, ГиПпиус 2012

АртАмонов Ю. А., ГипПиус А. А., “Древнерусские надписи Софии

Константинопольской”, в: К. В. Никифоров, отв. ред., Славянский альманах 2011, Москва, 2012, 41-52.

АРТАМОНОВ, ГИППИУС, ЗАЙЦЕв 2012

АрТАмонов Ю. А., ГИППИУС А. А., ЗАЙЦЕв И. В., “Древнерусские надписиграффити Константинопольской Софии: Предварительные итоги исследования”, в: В. Б. ПерХАвко, сост., 1150 лет Российской государственности и культуры: Материалы к Общему собранию Российской академии наук, посвященного Году российской истории (Москва, 18 декабря 2012 г.), Москва, 2012, 282-292.

2013

АртАмонов Ю. А., ГиППиУс А. А., ЗАЙЦЕв И. В., “«И с отцом, и с матерью, и со всею братьею... : Два древнерусских граффито из базилики Рождества Христова в Вифлееме”, Древняя Русь: Вопросы медиевистики, 2 (52), 2013, 86-91.

ВАСИЛЬЕВ 2005

ВАСильЕв В. Л., Архачческая топонимия Новгородской земли (Древнеславянские деантропонимные образования), Великий Новгород, 2005.

2012

ВАСиЛЬЕв В. Л., Славянские топонимические древности Новгородской земли, Москва, 2012 .

ГиПпиус, Михевв 2013

Гиппиус А. А., МихеЕв С. М., “О подготовке Свода надписей-граффити Новгородского Софийского собора”, в: А. М. МолдовАн, отв. ред., Письменность, литература, фольклор славянских народов. История славистики: ХV Международный съезд славистов. Минск, 20-27 августа 2013 г.: Доклады российской делегащии, Москва, 2013, 152-179. 


\section{ДЕЛ’АГАТА 1978}

ДЕл’АгАТА Дж., “Стари кирилски надписи в катедралата «Сан Мартино» в град Лукка”, в: Н. ТОДОРОВ, В. ТЫПКОВА- ЗАИМОВА, Н. ДРАГОВА, М. ЖЕЧЕВ, Л. ГЕНОВА, реД., СлавЯНСКИе культуры и Балканы, 1: IX-XVII вв., София, 1978, 62-65.

\section{ЗАлизняк 1986}

ЗАлизняк А. А., “Новгородские берестяные грамоты с лингвистической точки зрения”, в: В. Л. Янин, А. А. ЗАлизняк, Новгородские грамоты на бересте (из раскопок 19771983 г2.). Комментарии и словоуказатель к берестяным грамотам (из раскопок 19511983 г2.), Москва, 1986, 89-219.

\section{0}

ЗАлизняк А. А., “Палеография берестяных грамот и их внестратиграфическое датирование”, в: В. Л. Янин, А. А. ЗАлизняк, Новгородские грамоты на бересте, 10: (Из раскопок 1990-1996 г2.). Палеография берестяных грамот и их внестратиграфическое датирование, Москва, 2000, 134-429.

2004

ЗАлизняк А. А., Древненовгородский диалект, 2-е изд., перераб. с учетом материала находок 1995-2003 гг., Москва, 2004.

ИТКИН, КОГАН 2006

Иткин И. Б., КогАн Ю. К., “Окончание дательного падежа -ови в древненовгородском диалекте”, Русский язык в научном освещении, 2 (12), 2006, 204-212.

КАЛЕЧЫЦ 2011

КАЛЕчЫЦ І. Л., Эпіграфіка Беларусі X-XIV стст., Мінск, 2011.

\section{Корнієнко 1-3}

Корнієнко В. В., Корпус графіті Софії Київської (XI - початок XVIII cm.), 1-3, Київ, 2010-2011.

\section{МЕДЫНЦЕвА 1978}

Медынцева А. А., Древнерусские надписи новгородского Софийского собора:XI-XIV века, Москва, 1978.

$$
2000
$$

Медынцева А. А., Грамотность в Древней Руси: По материалам эпиграфики Х - первой половины ХІІІ века, Москва, 2000.

\section{Морошкин 1867}

Морошкин М., Славянский именослов, или Собрание славянских личных имен $в$ алфавитном порядке. = Onomasticon Slavicum, seu Collectio Personalium Slavicorum Nominum, С.-Петербург, 1867.

Мусин 2009

Мусин А. Е., “Паломничество в Древней Руси: исторические концепции и археологические реалии”, в: Л. А. БЕляЕв, ред.-сост., Archeologica Abrahamica: Исследования в области археологии и художественной традици иудаизма, христианства и ислама, Москва, 2009, 231-272.

НПЛ

НАсонов А. Н., ред., Новгородская первая летопись старшего и младшего изводов, Москва, Ленинград, 1950.

СоБолЕвский 1907

СоБолевский А. И., Лекции по истории русского языка, 4-е изд., Москва, 1907.

ФРАНКЛИН 2010

ФРАнклин С., Писъменность, общество и культура в Древней Руси (около 950-1300 г2.), С.-Петербург, 2010. 


\section{References}

Artamonov Yu. A., Gippius A. A., "Drevnerusskie nadpisi Sofii Konstantinopol'skoi,” in: K. V. Nikiforov, ed., Slavianskii al'manakh 2011, Moscow, 2012, 41-52.

Artamonov Yu. A., Gippius A. A., Zaitsev I. V., "Drevnerusskie nadpisi-graffiti Konstantinopol'skoi Sofii: Predvaritel'nye itogi issledovaniia," in: V. B. Perkhavko, ed., 1150 let Rossiiskoi gosudarstvennosti $i$ kul'tury: Materialy $k$ Obshchemu sobraniiu Rossiiskoi akademii nauk, posviashchennogo Godu rossiiskoi istorii, Moscow, 2012, 282-292.

Artamonov Yu. A., Gippius A. A., Zaitsev I. V., “«I s ottsom, i s mater'iu, i so vseiu brat'eiu...»: Dva drevnerusskikh graffito iz baziliki Rozhdestva Khristova v Vifleeme," Drevniaia Rus': Voprosy medievistiki, 2 (52), 2013, 86-91.

Buffat L., Schneider L., Hartmann-Virnich A., "Saint-Gilles: Les Jardins du Cloître," Bilan scientifique de la région Languedoc-Roussillon 2010, 2011, 85-86.

Dell'Agata G., "Antiche iscrizioni cirilliche nel Duomo di Lucca," Ricerche slavistiche, 20-21, 19731974, 5-14.

Dell’Agata G., "Stari kirilski nadpisi v katedralata «San Martino» v grad Lukka," in: N. Todorov, V. Typkova- Zaimova, N. Dragova, M. Zhechev, L. Genova, eds., Slavianskie kul'tury i Balkany, 1: IXXVII vv., Sofia, 1978, 62-65.

Echtenacher G., Hartmann-Virnich A., Hansen H., "Reconstructing the Building Process of Saint-Gilles-du-Gard Abbey. 3-D Modelling as an Instrument for Archaeological Analysis of Historic Architecture. Work in progress," in: C. Pere, J. Rollier-Hanselmann, eds., Proceedings of the International Conference. Actes du colloque international Arch-I-Tech, Archéologie / architecture IngénierieTechnologie, Cluny, 17-19 novembre 2010, Bordeaux, 2011, 171-77.

Favreau R., Épigraphie médiévale, Turnhout, 1997.

Favreau R., Michaud J., Mora B., éd., Corpus des inscriptions de la France médiévale, 13: Gard, Lozère, Vaucluse, Paris, 1988.

Franklin S., Writing, Society, and Culture in Early Rus, c. 950-1300, Cambridge, 2002.

Franklin S., Pis'mennost', obshchestvo i kul'tura v Drevnei Rusi (okolo 950-1300 gg.), St. Petersburg, 2010.

Gippius A. A., Mikheev S. M., "O podgotovke Svoda nadpisei-graffiti Novgorodskogo Sofiiskogo sobora," in: A. M. Moldovan, ed., Pis'mennost', literatura, fol'klor slavianskikh narodov. Istoriia slavistiki: XV Mezhdunarodnyi s"ezd slavistov. Minsk, 20-27 avgusta 2013 g.: Doklady rossiiskoi delegatsii, Moscow, 2013, 152-179.

Hartmann-Virnich A., "Saint-Gilles-du-Gard. Projet de recherche AEGIDIANA," Bilan scientifique de la région Languedoc-Roussillon 2009, 2010, 9092.

Hartmann-Virnich A., "L'inscription de la fondation de l'abbatiale de Saint-Gilles-du-Gard: étude de cas d'un problème archéologique," in: R. Alcoy, G. Mallet, V. Lucherini, M. Gianandrea, éd., Le plaisir de l'art du Moyen Age. Commande, production et réception de l'œuvre d'art. Mélanges en hommage à Xavier Barral I Altet, Paris, 2012, 140148.

Hartmann-Virnich A., "Saint-Gilles. AEGIMAIOR ancienne abbatiale de Saint-Gilles-du-Gard," Bilan scientifique de la région Languedoc-Roussillon 2012, 2013, 100-101.

Hartmann-Virnich A., "Et le dessain dicelle nestre pas en forme deglize. Déchéance, infortune et réparation de l'abbatiale de Saint-Gilles-duGard aux XVI $\mathrm{X}^{\mathrm{e}}$ et $\mathrm{XVII}{ }^{\mathrm{e}}$ siècles," in: M. Jurkovic, éd., Mélanges en hommage à Jean-Pierre Caillet, Turnhout, 2013, 259-266.

Hartmann-Virnich A., Brun A.-S., Crespin A., Bonetti M.-P., Dabas M., Guibal F., Jallet-Pons C., Hansen H., Bénézet J., Palazzo-Bertholon B., Vacheyroux G., Projet collectif de recherche "AEGIMAIOR. L'ancienne abbaye de Saint-Gillesdu-Gard. Archéologie et histoire monumentale d'un site monastique majeur du Midi de la France." Rapport pour l'année 2012, Montpellier, 2013.

Hartmann-Virnich A., Hansen H., "SaintGilles, ancienne abbaye, programme de recherche franco-allemand ANR-DFG AEGIDIANA," Bilan scientifique de la région Languedoc-Roussillon 2010, 2010, 82-84.

Hartmann-Virnich A., Hansen H., "SaintGilles-du-Gard: L'église abbatiale et les bâtiments monastiques: Nouvelles recherches archéologiques," in: Hartmann-Virnich A., Hansen H., dir., L'ancienne abbaye de Saint-Gilles-du-Gard: Nouvelles recherches sur un monument majeur de l'art roman (= Bulletin monumental, 171/4), Paris, 2013, 293-339.

Hartmann-Virnich A., Hansen H., "Saint-Trophime in Arles und Saint-Gilles-du-Gard. Neuere und aktuelle archäologische Forschungen $\mathrm{zu}$ den romanischen Kirchenbauten und ihren Skulpturenfassaden an der provençalischen Via Egidiana," in: B. Nicolai, ed., Santiago de Compostela. Pilgerarchitektur und bildliche Repräsentation in neuer Perspektive. Arquitectura de peregrinación y representaciones iconológicas desde una nueva perspectiva. Pilgrimage Architecture and Pictorial Concepts in a New Perspective. Actes du colloque international, Berne, 25-27 mars 2010, Bern, 2014.

Itkin I. B., Kogan Yu. K., "Okonchanie datel'nogo padezha -ovi v drevnenovgorodskom dialekte," Russkii iazyk v nauchnom osveshchenii, 2 (12), 2006, 204-212. 
Kalechyts I. L., Epihrafika Belarusi X-XIV stst., Minsk, 2011.

Korniienko V. V., Korpus hrafiti Sofii Kï̈vs'koï (XI - pochatok XVIII st.), 1-3, Kiev, 2010-2011.

Kraack D., Lingens P., Bibliographie zu historischen Graffiti zwischen Antike und Moderne, Krems, 2001.

Leclercq H., "Graffites," in: Dictionnaire d'archéologie chrétienne et de liturgie, 6/2, Paris, 1925, 1501-1541.

Medyntseva A. A., Drevnerusskie nadpisi novgorodskogo Sofiiskogo sobora: XI-XIV veka, Moscow, 1978.

Medyntseva A. A., Gramotnost'v Drevnei Rusi: Po materialam epigrafiki $X$ - pervoi poloviny XIII veka, Moscow, 2000.

Miglio L., Tedeschi C., "Per lo studio dei graffiti medievali. Caratteri, categorie, esempi," in: P. Fioretti, ed., Storie di cultura scritta. Scritti per Francesco Magistrale, Spoleto, 2012, 605-628.

Musin A. E., "Palomnichestvo v Drevnei Rusi: istoricheskie kontseptsii i arkheologicheskie realii," in: L. A. Beliaev, ed., Archeologica Abrahamica: Issledovaniia $v$ oblasti arkheologii $i$ khudozhestvennoi traditsii iudaizma, khristianstva $i$ islama, Moscow, 2009, 231-272.

Musin A., "Z wiecznego Rzymu nad Bug - znaki pielgrzymie z Czermna (Czerwienia)," in: J. Bagińska, M. Piotrowski, M. Wołoszyn, red., Czerwień - gród między Wschodem a Zachodem: Katalog wystawy, Tomaszów Lubelski, Leipzig, Lublin, Rzeszów, 2012, 243-255.

Petrucci A., "Graffito”, in: Enciclopedia dell'arte medievale, 7, Roma, 1996, 64-66.

Treffort C., "Les «graffitis» sur tables d'autel aux époques pré-romane et romane. Note à propos des inscriptions de l'autel de Gellone," in: X. Barral i Altet, C. Lauranson-Rosaz, ed., Saint-Guilhem-leDésert. La fondation de l'abbaye de Gellone. L'autel médiéval. Actes de la table ronde d'août 2002, Aniane, 2004, 137-146.

Vasilyev V. L., Arkhaicheskaia toponimiia Novgorodskoi zemli (Drevneslavianskie deantroponimnye obrazovaniia), Veliky Novgorod, 2005.

Vasilyev V. L., Slavianskie toponimicheskie drevnosti Novgorodskoi zemli, Moscow, 2012.

Zalizniak A. A., "Novgorodskie berestianye gramoty s lingvisticheskoi tochki zreniia," in: V. L. Yanin, A. A. Zalizniak, Novgorodskie gramoty na bereste (iz raskopok 1977-1983 gg.). Kommentarii $i$ slovoukazatel' $k$ berestianym gramotam (iz raskopok 1951-1983 gg.), Moscow, 1986, 89-219.

Zalizniak A. A., "Paleografiia berestianykh gramot i ikh vnestratigraficheskoe datirovanie," in: V. L. Yanin, A. A. Zalizniak, Novgorodskie gramoty na bereste, 10: (Iz raskopok 1990-1996 gg.). Paleografiia berestianykh gramot $i$ ikh vnestratigraficheskoe datirovanie, Moscow, 2000, 134-429.

Zalizniak A. A., Drevnenovgorodskii dialekt, 2nd ed., Moscow, 2004.

Anne-Sophie Brun, MA

Laboratoire d'Archéologie Médiévale et Moderne en Méditerranée LA3M UMR 7298, Aix-Marseille Université / Centre National de la Recherche Scientifique Maison Méditerranéenne des Sciences de l'Homme, BP 647, 5 Rue du Château de l'Horloge, 13094 Aix-en-Provence Cedex

France

asophie.brun@gmail.com

Prof. Andreas Hartmann-Virnich, Dr. habil.

Laboratoire d'Archéologie Médiévale et Moderne en Méditerranée LA3M UMR 7298, Aix-Marseille Université / Centre National de la Recherche Scientifique

Maison Méditerranéenne des Sciences de l'Homme, BP 647, 5 Rue du Château de l'Horloge, 13094 Aix-en-Provence Cedex

France

hartmann-virnich.andreas@neuf.fr 
Estelle Ingrand-Varenne, $\mathrm{PhD}$

Centre National de la Recherche Scientifique,

Centre d'Études Supérieures de Civilisation Médiévale

Hôtel Berthelot, TSA 81118, 24 rue de la Chaîne, 86073 Poitiers Cedex 9

France

estelle.ingrand.varenne@univ-poitiers.fr

Савва Михайдович Михеев, канд. ист. наук

Институт славяноведения РАН, старший научный сотрудник

Отдела типологии и сравнительного языкознания

119991 Москва, Ленинский проспект, д. 32а

Россия/Russia

mikheev@gmail.com 